\title{
Literatura i espiritualitat en els textos valencians del segle XV
}

\author{
Literature and spirituality in 15th. century valencian texts
}

\author{
AnNa I. Peirats \\ anna.peirats@ucv.es \\ Universidad Católica de Valencia San Vicente Mártir
}

Durant el Segle d'Or valencià (segle XV) van veure la llum alguns dels grans clàssics de la literatura escrita en la nostra llengua. Una part important d'aquest ric cabal literari és conformada per obres de temàtica religiosa $\mathrm{o}$, si més no, impregnades d'una profunda dimensió espiritual. Així, entre el tombant del tres-cents i els inicis del quatre-cents trobem la figura fonamental del frare franciscà Francesc Eiximenis i del dominicà sant Vicent Ferrer, que duu a terme la seua intensa activitat homilètica per tot l'Occident europeu. És el segle de la novel la cavalleresca de Martorell, el Tirant lo Blanch, del poeta de l'amor espiritual Ausiàs March, de l'Spill de Jaume Roig, obra en vers que parteix d'un component misogin al servei de l'adoctrinament del receptor. Per la seua banda, la prosa de la influent abadessa de la Trinitat sor Isabel de Villena, autora de la Vita Christi, destaca per una prodigiosa imaginació, que està immersa en la tradició de les vides de Jesucrist, escrites durant els darrers segles medievals, una tradició dins la qual ocupa un paper important també Lo Cartoixà de Joan Roís de Corella. Atés que l'època medieval està marcada pel teocentrisme i per la idea fixada de la salvació espiritual de l'ànima, s'explica la proliferació de literatura espiritual, al servei didàctic i moralitzador d'evitar caure en el pecat pel temor al Judici Final i a la mort a les tenebres de l'infern.

El present monogràfic, dedicat a la literatura i a l'espiritualitat dels textos medievals valencians aplega 8 articles, que se centraran en el vessant històric, teològic i literari d'alguns dels principals exponents medievals. Des d'aquest punt de partida, l'article de Miguel Navarro Sorní, de la Facultat de Teologia de València, amb el títol «L'espiritualitat de sant Vicent Ferrer en el context de la seua època» cohesiona i inicia el volum, per tal com permet emmarcar l'espiritualitat de sant Vicent en el context històric del moment, fet que condiciona la seua espiritualitat. En aquest sentit, l'article 
del dr. Navarro insisteix en la figura del dominic valencià més enllà de la imatge de taumaturg o de sant obrador de miracles, o més encara, un predicador que enlaira el dit índex per tal d'espantar els receptors sobre la vinguda del Judici Final. En aquestes pàgines, Navarro se centra en la importància de la predicació vicentina basada en l'Evangeli, fet que cohesiona la seua doctrina i la seua homilètica.

La segona de les contribucions, a càrrec d'Albert Toldrà, de la Universitat de València, «El més enllà en sant Vicent Ferrer, Francesc Eiximenis i sor Isabel de Villena. Els llimbs dels patriarques» centra l'interés d'estudi de l'espiritualitat del segle XV en la visió que tant els predicadors com l'abadessa valenciana presenten del llimbs dels patriarques o sina d'Abraham, espai en què habiten els personatges de l'Antic Testament abans de ser deslliurats amb la ressurrecció de Crist. Aquesta devallada de Crist als llimbs es descriu també des del punt de vista que atorga la tradició textual i iconogràfica al fet que no pocs patriarques assumeixen el privilegi de ser testimonis directes de la visió de Crist crucificat.

Una altra de les contribucions que cohesionen el present volum és la de Marinela Garcia, de la Universitat d'Alacant, amb l'article «Algunes dades sobre la transmissió de les vides de sants entre l'Edat Mitjana i l'època moderna a la Corona d'Aragó», que rebla el clau al voltant de la proliferació de textos didàctics i doctrinals escrits en valencià, les anomenades vides de sants, que constitueixen models a seguir, a causa de l'impacte que produïen aquestes vides, a tots els nivells de la societat i de la cultura popular, més enllà del vessant literari. L'article de Marinela incideix a remarcar el mode en què es transmetien els textos de les vides, difoses en diverses versions i modes de compilació.

En aquesta línia del punt de vista didàctic que cal remarcar en els textos medievals de temàtica espiritual, l'article d'Anna Isabel Peirats, de la Universitat Catòlica de València, «La Vita Christi d'Isabel de Villena, misericòrdia restaurativa i profitosa doctrina al servei de la meditació» presenta una lectura de la Vita Christi més enllà dels comentaris que situen l'obra com a exponent de literatura en defensa de les dones o com a rèplica de l'Spill de Jaume Roig. En aquest article, la dra. Peirats parteix de la descripció de l'estil afectiu, així com de la presència de les dones que envolten la figura de Jesucrist, des del vessant de la Devotio Moderna, a mode d'ars meditandi, alhora que s'insisteix en la intenció doctrinal i didàctica de l'obra. A més a més, el concepte de misericòrdia restaurativa suposa una lectura de la Vita Christi des dels personatges masculins i femenins que en l'obra de Villena són redimits i situats en un bon lloc en el Regne dels cels, com a mèrit pels seus actes virtuosos.

L'article d'Aniello Fratta, «Una possibile parabola corellana: dal paradosso amoroso rivisitato alla poesia religiosa», se centra en l'anàlisi de l'evolució de la filogínia de Corella, en el context de la seua prolífica obra literària, des d'una relectura dels poemes de Jaufré Rudel, en el sentit que en diverses avinenteses, com ara la Tragèdia de Caldesa, la tendència de l'amant a morir per l'estimada evoca la concepció d'un amant cortesà que inspira una poesia amorosa en Corella de to místic i religiós. 
També al voltant de Roís de Corella, l’article de Josep Lluís Martos, de la Universitat d'Alacant, «La poesia en la prosa de Joan Roís de Corella: delimitació i transmissió del corpus» presenta un punt de vista novedós, per tal com delimita un corpus de vint-i-un poemes dins de la producció en prosa de Corella i estudia el mode de transmissió d'aquests textos, entre els quals consten poemes que s'insereixen en obres religioses en prosa, juntament amb altres obres profanes.

Al servei de fomentar l'espiritualitat a través de la novel la cavalleresca, l'article d'Anton M. Espadaler, de la Universitat de Barcelona, «Religió i religiositat en el Tirant lo Blanch» descriu dues formes de fer palés el tema religiós al Tirant lo Blanch: d'una banda, aquella que té a veure amb l'ideal de croada, des d'una vivència externa del cristianisme, i d'altra banda, la tendència a respectar els articles de la fe i contribuir al fet que els personatges que donen vida a la trama argumental actuen d'acord amb una conducta preceptiva d'acord amb l'època en què es va escriure la novel la.

L'últim dels articles, a càrrec de Dominique de Courcelles (Paris Sciences Lettres Université de la recherche, CNRS- Ecole normale supérieure Ulm) «Amour et mort, vie de sainteté dans la littérature et la spiritualité à València au XVème siècle: de saint Vicent Ferrer à Sor Isabel de Villena», clou aquest volum dedicat a l'espiritualitat i la literatura en els textos valencians del segle $\mathrm{XV}$, atés que situa l'anàlisi dels temes de l'amor i la mort en el context de la història de la literatura i de l'espiritualitat en el context de la història religiosa de la Península Ibèrica. En aquest sentit, segons De Courcelles, l'aportació de la predicació vicentina contribueix a la reforma moral de la societat, i entén que els autors valencians del segle XV presenten un univers de cavallers i religiosos que defensen els valors del cristianisme, la veritat, la pau i la justícia, com és el cas de l'anònim text de Curial e Güelfa, el Cant espiritual d'Ausiàs March, el Tirant lo Blanc, en què conflueix la cavalleria i l'espiritualitat, fins a Isabel de Villena, abadessa de la Trinitat, autora d'una Vita Christi que anuncia una necessària conversió interior, des de la meditació i el seguiment de Crist com a model de vida espiritual. 